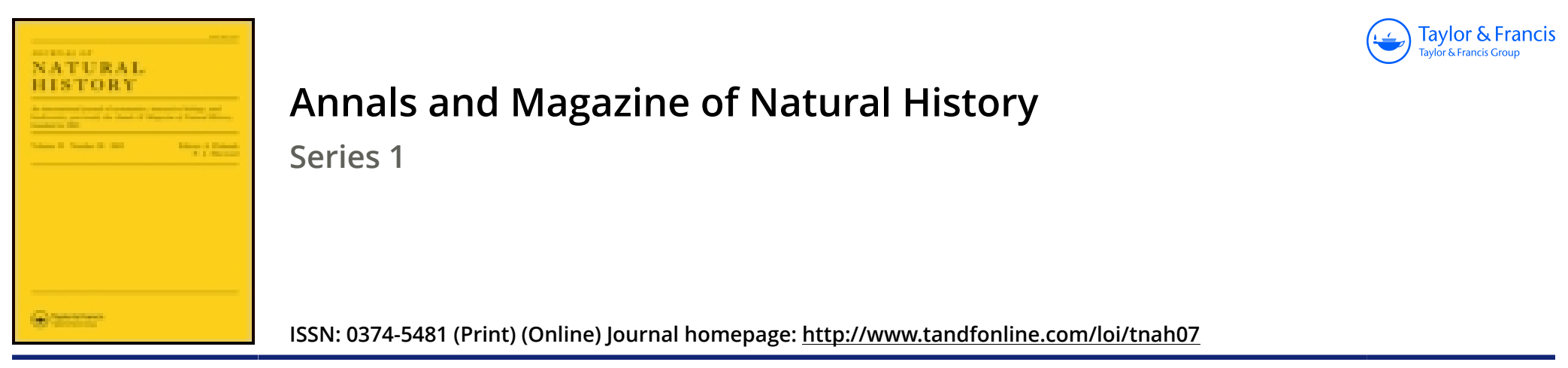

\title{
XVII.-Notes on Phrynosoma Harlani, Wieg.
}

\section{Dr. Patrick Neill}

To cite this article: Dr. Patrick Neill (1846) XVII.-Notes on Phrynosoma Harlani, Wieg. , Annals and Magazine of Natural History, 17:110, 99-100, DOI: 10.1080/037454809495565

To link to this article: http://dx.doi.org/10.1080/037454809495565

册Published online: 17 Dec 2009.

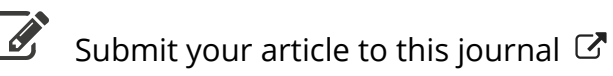

Q View related articles $₫$ 
they then still enjoy all the properties of these spheres, so that after their incorporation they continue for a certain time to multiply by subdivision, as we shall show in a future memoir.

XVII.-Notes on Phrynosoma Harlani, Wieg. By Dr. Patrick Neill.

Dear Sir,

IN the autumn of 1844 I was presented with a beautiful specimen of the Phrynosoma Harlani by a gentleman who had brought it direct from Texas. After keeping it a week or two the creature was sent to my friend Dr. Neill, and the inclosed letters relating to its habits appear to me of sufficient interest to warrant their publication.

I am, dear Sir, yours very truly,

Richard Taylor, Esq.

Geokge Johnston.

My Dear Sir,

Canonmills, Dec. 28, 1844.

The curious Texas Lizard, after six weeks' residence in my hothouse, is still alive, and taking a fly when we can tempt him with a living one.

On procuring Dumeril and Bibron from my friend $\mathrm{Mr}$. Wilson, I found a full and accurate description of the animal, Phrynosoma Harlani of Wiegmann, Agama cornuta of Harlan, and apparently Lacerta orbicularis of Linnæus. The coloured figure in Griffith's ' Règne Animal' seems to have been taken from a museum specimen, for the bright colours are deficient: what is pale brown in Griffith's figure, is in the living subject, when lively and in a temperature of $65^{\circ}$ or $70^{\circ} \mathrm{F}$., golden yellow. The description of the colours is, to some extent, liable to the same exception.

Fortunately flies are found in our steam-engine room all the winter, and I carry home two or three in a small box every Saturday. Phrynosoma is rather cunning or suspicious; for we have been unable to see him eatch at a fly, so as to know whether he throws out the tongue as the chameleon used to do. The gardener has watched ten minutes in vain; yet if he leaves a disabled fly with him for five minutes, the fly has disappeared on his return. He can climb the perpendicular smooth wooden wall of a box in which we keep him and can adhere to the wall. He can leap somewhat like a frog, or rather like a toad-clumsily and to a small distance only -not twice the length of his own body. Miss Neill thinks she heard him utter a kind of squeaking croak, but neither the gar- 
dener nor $I$ have heard any voice.-[The large long-necked tortoise fuffs like a cat very often.]

\title{
Dr. Johnston.
}

\author{
I remain, dear Sir, yours very truly, \\ Patrick Neill.
}

Mr Dear Srr,

The Phrynosoma, I regret to say, unexpectedly died about a week ago. I am not aware of having been able to make any observations in addition to those I formerly communicated.

We had a chamber made for it just over the entrance of the flue, and where the temperature was scarcely ever so low as $60^{\circ} \mathrm{F}$., and often $70^{\circ}$ and upwards: we kept a shallow saucer with water in the chamber, and always some Hypnum moss or foreign Lycopodium laid over the saucer, so that the lizard could drink and could not overturn the vessel or spill the water. The creature often sat on the top of the moss.

Dr. Johnston.

Dear Sir, yours very truly,

Patrick Neill.

XVIII.—On the Relations of the genus Noggerathia to Living

Plants. By M. Adotphe Broveniart*.

Tue difficulties in determining the relations of fossil plants to those now in existence have long been known. The isolation of the different parts of a plant, and in most cases their imperfect state of preservation, which obliges the naturalist to be satisfied with the examination of characters which are frequently the least important, are the principal obstacles to this study. The more the plants, the remains of which are submitted to our investigation, differ in their organization from those which are the constant studies of the botanist, so much the more difficult is the establishment of their analogies. The further we proceed in the series of ages towards the earliest geological periods, the further are we removed from the actual creation, and the greater do the differences between the living and fossil beings become; this general law is well-established in the animal kingdom, and it is not less true for the vegetable world.

Thus most of the fossil plants of the tertiary strata belong to genera in actual existence, and merely present specific differences; such are the pines, elms, birches, maples, walnut-trees, Nymphae, \&c.

Those of the secondary strata may undoubtedly almost always be referred to known families, but appear in most cases to require the formation of new genera.

Lastly, in the older strata, particularly in the coal-formations,

* Translated from the Comptes Rendus for December 29, 1845. 